\title{
LAVINIA BRANCUS-CIEŚLAK
}

Uniwersytet Kardynała Stefana Wyszyńskiego

\section{SZANSE ARBITRAŻU W ROZWIAZZYWANIU SPORÓW NA TLE DOMEN INTERNETOWYCH}

Rozwiązywanie konfliktów pomiędzy dysponentami domen internetowych a uprawnionymi ze znaków towarowych okazuje się trudne do zrealizowania przy wykorzystaniu zwykłej drogi sądowej. W warunkach rosnącej liczby tego typu konfliktów oraz ich specyficzności konieczne jest stosowanie odpowiedniego narzędzia ochronnego. Takim środkiem jest arbitraż ${ }^{1}$. Zapewnia on szybkie rozpoznanie i rozstrzygnięcie sprawy przez prawników posiadających odpowiednią znajomość problematyki domen przy stosunkowo niskich kosztach.

Jedną z najbardziej popularnych światowych procedur arbitrażowych cieszącą się ogromnym powodzeniem na tle sporów domenowych, jest „Jednolita Polityka Koncyliacyjna odnośnie Domen Internetowych" (Uniform Domain Name Dispute Resolution Policy - dalej UDRP). Została ona przyjęta 24 października 1999 r. przez amerykańską organizację o nazwie ICANN (Internet Corporation for Assigned Names and Numbers) ${ }^{2} \mathrm{i}$ obecnie jest sto-

\footnotetext{
${ }^{1}$ Ściślej mówiąc, procedura mediacyjna-arbitrażowa, bardzo popularna na rynkach anglo-amerykańskich, gdzie nosi nazwę ,alternative dispute resolution" (w skrócie ADR, tj. alternatywne sposoby rozstrzygania konfliktów).

${ }^{2}$ ICANN aktualnie zarządza serwerami, na których przechowane są wszystkie domeny generyczne (m.in. ,.com”, ,.org”, ,.int”) i domeny krajowe (m.in. polskie
} 
sowana m.in. przez renomowaną Międzynarodową Organizację Własności Intelektualnej (Worldwide Intellectual Property Organisation, dalej WIPO) ${ }^{3}$.

Próby podobnych rozwiązań obserwujemy również w Polsce. W styczniu 2003 r., w wyniku współpracy pomiędzy Polską Izbą Informatyki i Telekomunikacji (dalej "PIIT”)4 a Naukową Akademią Sieć Komputerowa ${ }^{5}$ (dalej „NASK”), powołany został Sąd Polubowny ds. Domen Internetowych (dalej „Sąd”). Stworzony został on w celu rozwiązania konfliktów na tle polskich nazw domenowych. Polskie postępowanie arbitrażowe oparte jest na stosownym regulaminie i rożni się w nieznacznym stopniu od UDRP. Sąd działa na podstawie regulaminu (tj. „Regulaminu Sądu Polubownego ds. domen internetowych przy PIIT”, dalej „Regulamin”) uchwalo-

„.pl”) i w związku z tym, odpowiedzialny jest również za koordynowanie, ujednolicanie i zarządzanie calą polityką nazewniczą w Internecie. Każdy podmiot odpowiedzialny za rejestrację i utrzymanie domen krajowych, w tym również polski NASK, zobowiązany jest do uiszczenia określonej oplaty na rzecz ICANN, z tytułu swiadczonych przez niego usług, bez których niemożliwe byłoby funkcjonowanie krajowych zasobów internetowych.

${ }^{3}$ UDRP jest to rodzaj procedury arbitrażowej o zasięgu ogólnoświatowym, opartej na umowie stron, stosowanej przez prywatne podmioty. Uregulowana jest ona w dwóch aktach. Podstawowy tekst UDRP zawiera główne postanowienia dotyczące m.in. obligatoryjnego charakteru procedury, przedmiotowego zakresu ochrony (tj. rodzajów i przesłanek naruszeń objętych rozstrzygnięciem arbitrażowym), katalogu sankcji oraz skuteczności wydanej decyzji. Dostępny jest on na stronach www.icann.org/dndr/udrp/policy.htm. Drugi akt, o nazwie „Regulamin” (Rules) dotyczy aspektów proceduralnych związanych z postępowaniem arbitrażowym. Dostępny jest on na stronach www.icann.org/dndr/udrp/uniform-rules.htm.

${ }^{4}$ Przypominam, że PIIT stworzona została w styczniu 1993 r. na podstawie ustawy z dn. 30 maja 1989 r. o izbach gospodarczych, jako podmiot gospodarczy dzialający w sektorze teleinformatyki i telekomunikacji. Jedno ze zadań statutowych PIIT (pkt. 35 Statutu) stanowi właśnie polubowne rozstrzyganie spornych spraw gospodarczych, o ile strony zgodnie poddadzą spór pod arbitrażem Izby. Odnosi się to zarówno do sporów pomiędzy samymi przedsiębiorcami, jak i pomiędzy przedsiębiorcami a konsumentami.

${ }^{5} \mathrm{Tj}$. polski podmiot odpowiedzialny za zarządzaniem zasobami nazw domenowych zarejestrowanych w domenie generycznej ,. pl”. 
nego przez Walne Zgromadzenie PIIT'. Regulamin zawiera w znacznie mierze przepisy proceduralne niż materialne ${ }^{7}$. Innymi słowy, Regulamin jako jedyny akt określający zasady i tryb postępowania polubownego, reguluje takie istotne kwestie jak kognicja Sądu, katalog oraz przesłanki dochodzenia roszczeń, skuteczność orzeczeń wydanych przez Sąd. Stanowi to główny powód dla podjęcia w niniejszym opracowaniu próby rozważania części prawnych aspektów związanych z dochodzeniem roszczeń. Sąd działa od niedawna, a więc jakichkolwiek wnioski związane z praktyką wydają się być na tym etapie jeszcze przedwczesne.

\section{RODZAJE SPRAW ROZPOZNANYCH PRZEZ SAQD}

Sąd ds. Domen, ze względu na jego „polubowny” charakter, podlega również regulacji prawnej zawartej w księdze trzeciej Kodeksu postępowania cywilnego odnośnie sądownictwa polubownego (art. 1154-1217 k.p.c.) ${ }^{8}$. Część tych przepisów mają moc bezwzględnie obowiązującą, a więc charakter nadrzędny w stosunku do Regulaminu Sądu.

Jedno z najważniejszych zagadnień dotyczy zakresu spraw, które mogą podlegać sądownictwu polubownym. W świetle nowego art. 1157 k.p.c., strony mogą poddać pod rozstrzygnięcie sądu polubowne-

${ }^{6}$ Treść Regulaminu dostępna jest na stronie PIIT, tj. www.piit.org.pl. Niniejszy Regulamin został przyjęty przez Walne Zgromadzenie PIIT z 22 marca 2005 r. na miejsce zobowiązującego wcześniej „Regulaminu mediacji oraz arbitrażu w sprawach dotyczących nazw domen internetowych”. Warto zaznaczyć, iż oprócz zmiany nazwy, treść regulaminu pozostała bez zmian.

${ }^{7}$ Tym samym bardziej przypomina ww „Rules” - akt zawierający szczegóły postępowania arbitrażowego na tle UDRP.

${ }^{8}$ Por. art. 1154-1217 dodane przez art. 1 pkt 8 ustawy z 28 lipca 2005 r. (Dz.U. Nr 178, poz. 1478) jako część piąta kodeksu postępowania cywilnego z 17 listopada 1964 (Dz.U. Nr 43, poz. 296 ze zmian.). Zgodnie $z$ art. 1158 ust 2 k.p.c., przepisy niniejszej księgi stosują się zarówno do sądu polubownego powołanego do rozstrzygnięcia poszczególnego sporu (tzw. sądu ad hoc), jak i do stałego sądu polubownego. 
go spory o prawa majątkowe lub spory o prawa niemajątkowe z wyjątkiem sporów o alimenty. Stanowi to zasadniczą zmianę w stosunku do dawnego art. 697 § 1 k.p.c., który do tej pory ograniczał zakres zapisu na sąd polubowny jedynie do sporów o prawa majątkowe. W związku z tym w chwili obecnej spory o naruszenie dóbr osobistych mogą być rozpoznane przez sądownictwo polubowne, a wcześniej było to niedopuszczalne. Obejmuje to przykładowo sytuację, gdy dysponent domeny narusza prawo do nazwiska określonej osoby. Natomiast, w zakresie pojęcia „sporu o prawa majątkowe” mieszczą się naruszenia prawa do znaku towarowego lub do innych oznaczeń odróżniających przedsiębiorstwa, tak jak firma, nazwa handlowa lub logo.

Z postanowień Regulaminu wynika, iż stosuje się on wyłącznie do rozstrzygania sporów powstałych na tle rejestracji nazw domenowych z zakończeniem „.pl” (tj. nazwy zarejestrowanych w domenie generycznej „.pl”). Zgodnie z art. 2 ust. 4 Regulaminu, Sąd jest właściwy jedynie, gdy przynajmniej jedna ze stron (osoba fizyczna, prawna lub jednostka organizacyjna bez osobowości prawnej) ma miejsce zamieszkania lub siedzibę w Polsce. W przeciwnym przypadku, spory są rozpoznawane na odrębnych zasadach przez WIPO $^{10}$.

\section{OBLIGATORYJNOŚ\& POSTĘPOWANIA ARBITRAŻOWEGO}

Regulamin Sądu przewiduje dwojaką drogę dla dochodzenia roszczeń: mediację i/lub arbitraż. Mediacja gra tu wstępną rolę, al-

${ }^{9}$ Znak towarowy jest dobrem niematerialnym o podwójnej naturze, zawiera on splot interesów zarówno niemajątkowych jak i majątkowych, przy czym nie ulega wątpliwości, iż przeważającą rolę odgrywa majątkowy charakter. W związku z tym spory o naruszenie prawa do znaku towarowego należy również kwalifikować jako majątkowe. Por. np. E. Nowińska, U. Promińska, M. du Vald, [w:] Prawo wlasności przemystowej, Warszawa 2003, s. 233 i n.; B. Soltys, Charakter i konstrukcja prawa do znaku towarowego, «Rejent» 3.3-4 (1993), s. 68-73.

${ }^{10}$ Por. tekst regulaminu stosowanego przez WIPO odnośnie domen zarejestrowanych w końcówce „. pl” (pełna nazwa - WIPO Expedited Arbitration Rules for Domain Name Dispute Resolution under „.. pl”), w mocy od 20 stycznia 2003 r., dostępnego na stronie www.arbitraz.pl/en/doc/pl_wipo_expedited_arbitration_rules.pdf. 
bowiem przepis art. 5 ust. 2 Regulaminu stanowi, iż mediację mogą poprzedzać wszczęcie postępowania arbitrażowego. Wszczęcie postępowania należy do osoby, której naruszono prawa w wyniku rejestracji określonej domeny. Postępowanie jest zatem skierowane przeciwko dysponentowi tejże domeny (określonego przez Regulamin jako „abonenta nazwy domeny”). Jak wspomniałam wyżej, zgoda obu stron niezbędna jest dla uruchomienia postępowania polubownego zarówno na etapie mediacji (por. art. 5 ust. 3) jak i arbitrażu (art. 9 ust. 3). Pojawia się więc pytanie: czy oba te etapy postępowania są obligatoryjne i w związku z tym, czy dysponentowi domeny grozi jakaś sankcja w sytuacji uchylenia się od uczestniczenia w postępowaniu przed sądem.

W sytuacji wystąpienia przez osobę trzecią z wnioskiem o przeprowadzenie mediacji przeciwko abonentowi domeny ten ostatni ma 7 dni od doręczenia mu wniosku na wyrażenie zgody w sprawie mediacji (art. 6 ust. 3). Odmowa zgody lub bezskuteczny upływ terminu powoduje natychmiastowe umorzenie mediacji i utratę przez wnioskodawcę opłaty wstępnej ${ }^{11}$. Jeżeli abonent zgodzi się na mediację, ciężar finansowy postępowania rozłoży się pomiędzy strona$\mathrm{mi}^{12}$. W świetle Zasad Rejestracji i Utrzymywania Domen przyjętych przez NASK abonent nie ma obowiązku wyrażenia zgody na mediację $^{13}$. Co prawda w art. $14 \mathrm{zd}$. pierwsze Zasad mowa jest o tym, że „abonent przystąpi do postępowania mediacyjnego, opisanego w Regulaminie Sądu”, co mogłyby wskazywać na pewną powinność, jednak brak jest jakichkolwiek sankcji w sytuacji uchylenia się od wyrażenia zgody na mediację. Warto zauważyć, że nawet

${ }^{11}$ Jest to 500 PLN (vide art. 6 oraz rozdział odnośnie wykazu oplat Regulaminu).

${ }^{12}$ Każda ze stron zobowiązana jest uiścić opłatę ostateczną w wysokości 1000 PLN, przy czym opłata wstępna wnioskodawcy zaliczona jest na poczet ostatecznej. W sumie za przeprowadzenie negocjacji należy się 2000 PLN.

${ }^{13}$ Przypominam, że każda osoba dysponująca domeną zarejestrowaną w „.p pl" podlega regulaminowi uchwalonemu przez NASK o nazwie ,Zasady rejestracji i utrzymywania nazw domen internetowych" (dalej "Zasady"), ostatnia wersja z mocą od 20 stycznia 2003 r.; tekst dostępny na stronie www.dns.pl/zasady-p.html. 
w sytuacji gdy strony przystąpią do mediacji, ale nie osiągną żadnego porozumienia, możliwe jest ponowne dochodzenie roszczeń w postępowaniu arbitrażowym (art. 8 ust. 6 Regulaminu). Tym bardziej wydaje się być otwarta droga arbitrażowa, jeżeli postępowanie mediacyjne w ogóle zostało umorzone z powodu braku zgody abonenta. Z kolei, jeżeli strony osiągną kompromis w wyniku mediacji, to takie porozumienie wiąże strony i zostanie przekazane NASK do wykonania (art. 8 ust. 4). Wobec powyższego, należy uznać, iż postępowanie mediacyjne jest niezależne i fakultatywne w stosunku do postępowania arbitrażowego. Wniosek o mediację może doprowadzić do osiągnięcia porozumienia i szybkiego zakończenia sporu, ale niesie też ryzyko braku reakcji ze strony abonenta domeny, a więc straty czasu i nakładów finansowych wnioskodawcy.

Inaczej wygląda sprawa w sytuacji wniesienia pozwu w postępowaniu arbitrażowym. Regulamin NASK, podobnie jak regulamin UDRP, zmusza de facto abonenta domeny do podpisania zapisu na sąd polubowny ${ }^{14}$. Brak zgody obu stron na zapis oznaczy brak wszczęcia postępowania arbitrażowego (art. 9 ust. 3 Regulaminu). W związku z tym Zasady NASK nakładają na abonenta domeny obowiązek doręczenia sądowy arbitrażowemu podpisany zapis na sąd polubowny, nie później jednak niż w terminie wskazanym w wezwaniu do podpisania tego zapisu (art. 14 ost. zd. Zasad). Z tym wiążą się dla abonenta domeny określone sankcje wynikające $z$ umowy zawartej z NASK (art. 15 Zasad). Po pierwsze, abonent naraża się na wstrzymanie możliwości korzystania z nazwy domeny po upływie 30 dni od terminu wyznaczonego do podpisania zapisu. Po drugie, w rachubę wchodzi nawet rozwiązanie umowy (zawartej zwykle z NASK) o rejestrację i utrzymanie domeny z terminem 3 miesięcznego wypowiedzenia od momentu wyznaczonego do podpisania zapisu ${ }^{15}$. Innymi słowy, odmowa podpisania przez abo-

${ }^{14}$ Regulamin Sądu posługuje się pojęciem „klauzuli arbitrażowej”.

${ }^{15}$ Zgodnie z art. 14 zd. 2, ,jeżeli nie zostanie zawarta pomiędzy Abonentem i osobą trzecią ugoda, kończąca postępowanie mediacyjne, Abonent doręczy PIIT podpisany zapis na Sąd Polubowny, nie później jednak niż w terminie wska- 
nenta zapisu na sąd polubowny wiąże się z zawieszeniem domeny, a ostatecznie $z$ jej utratą.

Ze względu na powyższe sankcje można uznać, iż w stosunku do abonenta domeny postępowanie arbitrażowe ma w praktyce charakter obligatoryjny (rozumiany jako przymusowy). Nie chodzi tu jednak o obligatoryjność w znaczeniu prawnym. Sąd polubowny ds. Domen jest jedynie dogodniejszą alternatywą dla sądu zwykłego. Nie ulega wątpliwości, że każda ze stron może swobodnie decydować o dochodzeniu roszczeń bezpośrednio przed sądem zwykłym, w przeciwieństwie do drogi arbitrażowej. Jednakże dopóki strony obowiązuje ważny zapis na sąd polubowny, dopóty żadna z nich nie może żądać rozpoznania sprawy przez sąd państwowy. Oznacza to, iż w sytuacji, gdy jedna ze stron wytoczy powództwo wbrew istniejącemu zapisowi, powództwo ulega odrzuceniu, jednakże tylko na zarzut drugiej strony zgloszony przed wdanie się w spór co do istoty sprawy (art. 1165 ust. 1 k.p.c.). Z tego powodu zapis na sąd polubowny określa się jako negatywną przesłankę procesową o charakterze jedynie względnym.

Postanowienia regulaminu NASK (należy go kwalifikować jako wzorzec umowy w rozumieniu art. 384 i nast. kodeksu cywilnego) w zakresie dotyczącym sankcji stosowanych w razie odmowy zapisu mogą wywołać pewne wątpliwości. NASK ma pozycję monopolisty na rynku usług domenowych jako jedyny podmiot odpowiedzialny za zarządzanie zasobami domen zarejestrowanych w końcówce „pl”. Każda osoba, która chce dysponować domeną w końcówce „pl” i zawiera odpowiednią umowę o rejestrację oraz utrzymanie domeny musi przyjąć regulamin NASK. Warto się zastanowić, czy

zanym w wezwaniu do podpisania tego zapisu". Pewne nieścisłości redakcyjne mogą uzasadnić wniosek, iż brak porozumienia mediacyjnego oznacza automatycznie obowiązek doręczenia zapisu pod rygorem sankcji wyżej wspominanych, co nadawalyby charakter przymusowy również mediacji. Wydaje się jednakże, iż obowiązek podpisania zapisu wynika dopiero w sytuacji wytoczenia odrębnego powództwa w postępowaniu arbitrażowym, a więc w wyniku odpowiedniego wezwania abonenta przez Sąd, zgodnie z art. 9 ust. 1 Regulaminu, do podpisania klauzuli arbitrażowej. 
takie postanowienia, na których treść osoba zainteresowana (często jest to konsument) nie ma rzeczywistego wpływu, nie mogą być w pewnych warunkach uważane za niedozwolone postanowienia umowne w świetle art. $385^{1}$ k.c. Przykładowy katalog niedozwolonych postanowień umownych zawarty w art. $385^{3}$ k.c. zawiera m.in. klauzula dotycząca poddanie sprawy pod rozstrzygnięcie sądu polubownego (tj. narzucająca rozpoznanie sporu przez sąd polubowny zamiast sądu zwykłego, por. art. $385^{3}$ pkt 23 k.c.). Oczywiście, można wyobrazić sobie sytuację, gdy abonent domeny odmawia zapisu i w konsekwencji traci dostęp do domeny, a równocześnie dochodzi swoich praw w drodze zwykłego postępowania sądowego, próbując w ten sposób odzyskać z powrotem domenę. W praktyce jednak naraża się on na długoletni proces i znaczne koszty. Wobec powyższych wątpliwości, należałoby zatem uznać, iż postanowienia Zasad NASK oraz Regulaminu Sądu zakładające pierwszeństwa drogi arbitrażowej w rozwiązaniu sporów, nie powinno się stosować względem abonenta-konsumenta, tj. osoby fizycznej która zarejestrowała domenę do celów niezwiązanych bezpośrednio z jej działalnością gospodarcza lub zawodową (art. $22^{1}$ k.c.). Należy jednak zasygnalizować, iż obecnie ani Regulamin, ani Zasady NASK nie przewidują takiego wyłączenia w stosunku do abonenta-konsumenta ${ }^{16}$.

\section{KATALOG ROSZCZEŃ DOCHODZONYCH PRZED SĄDEM POLUBOWNYM}

Jedno z najbardziej istotnych zagadnień dotyczy rodzaju roszczeń, które mogą być dochodzone przed Sądem ds. Domen. Po-

${ }^{16}$ Warto zaznaczyć, iż w toku prac przygotowawczych na tle powolania sądu arbitrażowego, wyrażono wątpliwości odnośnie możliwości „wymuszania” zapisu na sąd polubowny w stosunku do abonenta-konsumenta. W jednym z raportów prac pojawiła się propozycja, aby w przypadku sporów, w których abonent jest konsumentem, traktować orzeczenie Sądu wyłącznie jako „opinię prawną”, którą NASK zobowiązuje przestrzegać. Na razie ta myśl nie znalazła odbicie w treści Regulaminu oraz Zasad NASK, wobec czego orzeczenie Sądu ma w stosunku do stron postępowania mocy wyroku w rozumieniu k.p.c. Por. pkt. 6 raportu nad uruchomieniem Sądu, dostępny na http:/www.arbitraz.pl/historia.html. 
równując z procedurą UDRP, gdzie wachlarz dostępnych roszczeń wynika jasno $\mathrm{z}$ treści podstawowego regulaminu ${ }^{17}$, polski Regulamin wykazuje niewłaściwą technikę redakcyjną. Katalog roszczeń, które można dochodzić przeciwko abonentowi domeny. nie wynika bezpośrednio ani z treści Regulaminu Sądu, ani z Zasad NASK. Pewne ustalenia można poczynić dokonując analizy systemowej tych dwóch dokumentów.

Regulamin w część dotyczącej mediacji przewiduje jedynie, iż osoba dochodząca zaniechania naruszeń swoich praw wstosunku do abonenta nazwy domeny może złożyć wniosek o przeprowadzenie mediacji (art. 5 ust. 1 Regulaminu) ${ }^{18}$. Chodziłoby więc o wystąpienie z typowym roszczeniem o zaniechanie naruszeń. Pozytywne rozstrzygnięcie wniosku doprowadziłoby do pozbawienia abonenta możliwości dalszego korzystania $\mathrm{z}$ domeny w formie dotychczasowej. W praktyce oznaczałoby to albo usunięcie domeny, albo dokonanie określonych zmian w nazwie domeny, albo przeniesienie delegacji domeny na powoda. Wszystkie te czynności zakładają dokonanie pewnych technicznych zabiegów ze strony NASK, który, jak wspominałam, zarządza serwerami, na których „wpisane” są domeny zarejestrowane w końcówce „. pl”. Takie rozumienie pojęcia „zaniechania naruszeń" wydaje się odpowiadać zapisowi Regulaminu, według którego porozumienie (mediacyjne) wiąże strony i zostanie przekazane NASK do wyk onania (art. 8 ust. 4 Regulaminu). Przekazać do wykonania NASK można jedynie to, na co NASK ma odpowiednie środki techniczne i jest w stanie zatem faktycznie wykonać. Nie ulega jednak wątpliwości, iż w drodze mediacji nie można

\footnotetext{
${ }^{17}$ Zgodnie $z$ art. 4 i) UDRP można dochodzić jedynie dezaktywacji domeny (,cancellation") lub jej przeniesienia (,transfer"). Niedopuszczalne jest dochodzenie roszczeń odszkodowawczych lub zwrotu bezpodstawnie uzyskanych korzyści. Dezaktywacja lub zmiana delegacji domeny przeprowadzone są przez podmiot odpowiedzialny za rejestracją domeny, po otrzymaniu odpowiedniej decyzji od organizacji arbitrażowej.

${ }^{18}$ Podobnym zwrotem posługują się Zasady NASK, gdzie mowa o „roszczeniu o zaniechanie naruszania praw w wyniku zarejestrowania nazwy domeny" (art. 14 Zasad).
} 
wystąpić ani z roszczeniami odszkodowawczymi, ani z roszczeniami o zwrot bezpodstawnie uzyskanych korzyści.

W części dotyczącej arbitrażu brakuje przepisu, który w sposób jasny określiłby, z jakim roszczeniem można wystąpić do Sądu. Regulamin wymaga jedynie, aby pośród elementów składających się na obowiązkową treść pozwu figurowało, „żą da nie stwierdze nia, że pozwany w wyniku rejestracji nazwy domeny, naruszył prawa powoda" (art. 10 pkt. II Regulaminu). Z literalnego brzmienia wynikałoby, że przedmiotem roszczenia byłoby jedynie ustalenie istnienia naruszenia prawa powoda. W tej sytuacji Sąd miałby ustalić, ze dokonane zostały określone czyny, w wyniku których naruszono praw (a) powoda. Odnosząc się do klasycznego podziału powództw w świetle teorii prawa procesowego należałoby zatem stwierdzić, że chodzi tu o wystąpienie z powództwem o ustalenie ${ }^{19}$. Przyjęcie tezy, że mamy do czynienia $z$ powództwem o ustalenie w świetle art. 189 k.p.c. nasuwa pewne trudności. Po pierwsze, nauka prawa uznaje, iż w trybie 189 k.p.c. można ustalić jedynie istnienie prawa lub stosunku prawnego, a nie stanów faktycznych (chyba że chodzi o fakty prawotwórcze). Ustalenie przez Sąd jedynie faktu, iz w wyniku rejestracji naruszono prawa powoda, może nasuwać zatem wątpliwości. Po drugie, wyrok ustalający ma powagę rzeczy osądzonej co do ustalonego prawa, ale nie nadaje się do egzekucji ( $z$ wyjątkiem częśsi orzeczenia co do kosztów). W takim orzeczeniu Sąd jedynie ustala, ale nic nie zasądza. Przymusowe wykonanie takiego orzeczenia nie wchodziłoby zatem w rachubę. Warto również zasygnalizować, iż Regulamin wyraźnie dopuszcza „możliwość dochodzenia przez powoda innych niż wymienione w pozwie roszczeń wobec pozwanego w odrębnych postępowaniach" (art. 10 ost. zdanie) ${ }^{20}$.

19 Pozostałe dwa, to powództwo o zasądzenie świadczenia oraz powództwo o ukształtowanie prawa lub stosunku prawnego. Por. J. JoDŁowsKi, Z. REICH, J. LAPIERre, T. Misiuk-JodŁowska, Postepowanie cywilne, Warszawa 2002, s. 244-248.

${ }^{20}$ Art. 10 posługuje się niekonsekwentnie pojęciem „roszczenia” w liczbie pojedynczej czy mnogiej. 
Powyższe wnioski upoważniają do postawienia pytania: czy celem nowo utworzonej polityki arbitrażowej dla sporów domenowych było umożliwienie dochodzenia zaniechania naruszeń w drodze mediacji, natomiast w drodze arbitrażu jedynie ustalenie istnienia naruszeń? Podtrzymując wątpliwości wynikające $z$ brzmienia Regulaminu, rozsądek każe przyjąć, iż z roszczeniem o zaniechanie naruszeń można wystąpić zarówno w postępowaniu mediacyjnym jak i arbitrażowym. Wbrew literalnemu brzmieniu Regulaminu to roszczenie stanowi prawidłowe żądanie wniosku/powództwa $a^{21}$. Jednakże wydaje się, że dla klasycznych roszczeń o odszkodowanie lub o zwrot bezpodstawnie uzyskanych korzyści, pozostaje jedynie możliwość wystąpienia do sądu powszechnego na zasadach ogólnych. Takie rozwiązanie byłoby podobne do UDRP oraz zgodne $\mathrm{z}$ funkcjonalnymi założeniami arbitrażu na tle domen internetowych. Chodzi o to, aby arbitraż doprowadził do szybkiego rozwiązania konfliktu (zwykle przez pozbawienie dostępu do spornej domeny), bez wnikania w skomplikowaną i czasochłonną sprawę roszczeń majątkowych. Powstaje również pytanie, czy można dochodzić zaniechania naruszeń bezpośrednio przed sądem powszechnym. Moim zdaniem tak, ponieważ postępowanie arbitrażowe jest tylko alternatywą dla osoby, której prawa naruszono. Pozostaje jej wybór, czy zwrócić się do sadu arbitrażowego ( $\mathrm{z}$ ograniczonym wachlarzem roszczeń), czy do zwykłego sądu.

Regulamin, inaczej niż UDRP ${ }^{22}$, nie definiuje samego pojęcia "naruszenia”, nie zawiera tym samym żadnych przesłanek materialnych, które przybliżałyby przedmiot ciężaru dowodu wniosko-

${ }^{21}$ Roszczenie polegające na zaniechaniu naruszeń zawiera automatycznie i a priori ustalenie, że określone naruszenie miało miejsce.

${ }^{22}$ Zgodnie $\mathrm{z}$ art. 4 a) UDRP, każda osoba może złożyć skargę przeciwko dysponentowi domeny, jeżeli spełnione są kumulatywnie następujące trzy przesłanki (I) nazwa domeny jest identyczna lub podobna w sposób stwarzający ryzyko konfuzji do znaku towarowego, do którego ta osoba ma prawo; (II) posiadacz domeny nie legitymuje się żadnym prawem lub usprawiedliwionym interesem w stosunku do spornej nazwy; (III) domena została zarejestrowana i jest używana w złej wierze. 
dawcy. Regulamin nie precyzuje czy naruszenie związane jest tylko z faktem rejestracji domeny, czy również z jej używaniem w obrocie, czy okoliczność posługiwania się w dobrej lub złej wiary będzie miała znaczenie. W art. 10 ii) Regulaminu mowa jest jedynie o naruszeniu wynikającym z rejestracji domeny. Nie ma żadnych wskazówek co do naruszenia wynikającego ze sposobu posługiwania się domeną w obrocie. Jeżeli decydująca ma być rejestracja, to w praktyce skuteczniej będzie można zwalczać zjawisko piractwa internetowego. Są to sprawy najliczniejsze, ale stosunkowo łatwe, biorąc pod uwagę skrajność naruszeń. O wiele trudniejsze są sytuacje kolizji oznaczeń wynikających z prawa do znaku towarowego, do firmy, do nazwy handlowej. Jeżeli dany podmiot zarejestruje domenę, w stosunku do której nazwy przysługuje mu określone prawo (np. ze znaku towarowego), ale używa ją w złej wierze i to używanie stanowi naruszenie prawa innej osoby, powstaje zatem pytanie, czy taki spór podlega również kompetencji sądu arbitrażowego, czy nie? Można przepuszczać, że założeniem polskiej polityki arbitrażowej jest rozpoznanie przez sąd polubowny wszystkich naruszeń na tle posługiwania się domenami, niezależnie od ich rodzajów. Obejmowałoby to zarówno naruszenia powstałe na tle samej rejestracji, jak i te związane z późniejszym używaniem domeny w obrocie. Niemniej jednak większa precyzja redakcyjna nie zaszkodziłaby również w tej kwestii.

\section{MOC PRAWNA ORZECZEŃ ARBITRAŻOWYCH}

Skuteczność wyroku sądu arbitrażowego stanowi zagadnienie o kluczowym znaczeniu. W tym punkcie Polski Regulamin różni się wyraźnie od UDRP ${ }^{23}$, ponieważ nadaje trwalszy charakter orzecze-

${ }^{23}$ Zgodnie $\mathrm{z}$ art. $4 \mathrm{k}$ ) UDRP decyzja zapadła na mocy procedury UDRP nie jest wiążąca dla stron i nie wyklucza dochodzenia tych samych roszczeń na drodze sądowej. Oznacza to również, iż sądy nie są związane rozstrzygnięciem UDRP i mogą wydać odmienne orzeczenie w tym samym stanie faktycznym. Z tych właśnie względów postępowanie UDRP przewiduje odpowiednie zabezpieczenie przed 
niom arbitrażowym. Otóż w świetle art. 30 ust. 1 Regulaminu, „arbiter rozstrzygając sprawę wydaje wyrok w rozumieniu przepisów postępowania cywilnego". Jest to bezpośrednie odesłanie do przepisów k.p.c. w części dotyczących sądownictwa polubownego ${ }^{24}$, co niesie niebagatelne konsekwencje. Po pierwsze, skuteczność orzeczenia sądu polubownego zależy od stwierdzenia jego wykonalności przez sąd powszechny, tak jak przewiduje zapis art. 1212 ust. 1 k.p.c. Oznacza to, iż wyrok nabywa pełną moc prawną na równi z wyrokiem państwowym dopiero po wydaniu przez zwykły sąd postanowienia o wykonalności. Odmowa stwierdzenia wykonalności (na które służy zażalenie) unicestwia jednak całe postępowanie przed sądem polubownym, a sprawa powinna być rozpoznana jeszcze raz od nowa ${ }^{25}$. W praktyce sąd powszechny nie kwestionuje dokonanych przez sąd polubowny ustaleń faktycznych ani stosowanego prawa materialnego ${ }^{26}$. Co do meritum sąd powszechny odmówi wydania tegoż postanowienia jedynie, gdy wyrok sadu polubownego jest sprzeczny z podstawowymi zasadami porządku prawnego RP (klauzula porządku prawnego z art. 1206 ust. 2 pkt 2 k.p.c.).

wykonaniem sankcji zawartych w decyzji arbitrażowej, a ulegających ewentualnie później zmianie na mocy wyroku sądu. Zgodnie z ww. art. 4 k), podmiot zarządzający rejestracją spornej domeny wykonuje decyzję UDRP polegającą na dezaktywacji lub przeniesieniu domeny, dopiero po upływie $10 \mathrm{dni}$ od jej otrzymania. Jeżeli w tym terminie podmiot rejestrujący otrzymuje od dysponenta domeny dowód wytoczenia odrębnego postępowania sądowego, wstrzyma się od wykonania sankcji UDRP do momentu definitywnego zakończenia sporu. Po uptywie tego termi$\mathrm{nu}$, domena będzie dezaktywowana albo przeniesiona na inny przedmiot, a dysponent może uzyskać z powrotem do niej dostęp, dopiero w sytuacji korzystnego dla siebie orzeczenia sądowego.

${ }^{24}$ Por. art. 1212-1217 k.p.c.

${ }^{25}$ Por. T. EReciński, J. Gudowski, Komentarz do kodeksu postępowania cywilnego ${ }^{5}$, II, Warszawa 2004, s. 404-406.

${ }^{26}$ Sąd polubowny nie jest związany przepisami prawa materialnego ( $\mathrm{z}$ wyjątkiem tych, których naruszenie uchybiałoby wymogom praworządności), może więc rozstrzygnąć sprawę kierując się samymi zasadami sluszności. Por. treść art. $1194 \mathrm{w}$ zw. z art. 1214 ust. 3 k.p.c. Por. również uwagi J. JoDłowski, Z. REICH, J. LAPIERRE, T. MisIUK-JODEOWSKA, op. cit., s. 393. 
Nawet jeśli sąd powszechny nie bada merytorycznej zasadności orzeczenia sądu arbitrażowego, musi on zapoznać się ze sprawą i rozumieć stan faktyczny, co biorąc pod uwagę nowość i specyficzność konfliktów internetowych, nie zawsze będzie zabiegiem oczywistym. Te aspekty na pewno rzutują na długość całego postępowania i ostatecznego rozwiązania sporu.

Po drugie, orzeczenie sądu arbitrażowego jest wiążące dla stron i nie podlega odwołaniu do sądu powszechnego. Obecnie, strony mają możliwość zawarcia w samym zapisie na sąd polubowny klauzuli powołującej sąd polubowny drugiej instancji (zob. art. 1205 ust. 2 k.p.c.). Owszem, istnieje możliwość wytoczenia przed sądem powszechnym skargi o uchylenie wyroku sądu arbitrażowego na warunkach określonych w art. 1205 i nast. k.p.c., jednakże sąd powszechny w tej sytuacji nie orzeka merytorycznie co do istoty sprawy. Może tylko oddalić skargę lub uchylić wyrok, wskutek czego postępowanie w sprawie rozpoczyna się od nowa. Wydaje się więc, że treść wyroku arbitrażowego w zakresie oceny jego zasadności, właściwego stosowania prawa materialnego, prawidłowości ustaleń faktycznych, nie podlega w zasadzie kontroli ${ }^{27}$.

W tym momencie należy przyjść do kolejnej znaczącej kwestii. Otóż orzeczenie sądu polubownego, w stosunku do którego stwierdzono wykonalność, staje się prawomocne, co wyraża się zarówno w jego prejudycjalności (w rozumieniu art. 365 k.p.c.), jak

${ }^{27}$ Dawny art. 712 ust. 1 pkt 4 k.p.c. przewidywal, iż jedna $z$ podstaw skargi może stanowić niezrozumiałość i/lub sprzeczność orzeczenia, albo uchybienie praworządności lub zasadom współżycia społecznego. Na tym tle w literaturze przedmiotu uważano powszechnie, iż powyższe zarzuty nie należy utożsamiać z zarzutem mylnego rozstrzygnięcia pod kątem prawnym lub faktycznym. Ten ostatni zarzut w ogóle nie był brany pod uwage przed sąd powszechny rozpoznający skargę. Por. T. ERecinski, J. Gudowski, Komentarz, II, cit., s. 410-411. Treści aktualnego art. 1206 k.p.c. nie zawiera już ww podstawy skargi; w wyniku przeredagowania zachowała się jedynie klauzula porządku publicznego (tj. wyrok jest sprzeczny z podstawowymi zasadami porządku prawnego RP). Tym bardziej więc w świetle aktualnego stanu prawnego sąd zwykly nie będzie kontrolowal orzeczenie sądu polubownego pod katem prawidłowości ustaleń faktycznych. 
i w korzystaniu z powagi rzeczy osądzonej (366 k.p.c.). Oznacza to m.in., iż zakres przedmiotowy rozstrzygnięcia sądu arbitrażowego, a w tym jego podstawa faktyczna, będą wiążące dla innych sądów. Wyłączone będzie więc ponowne rozpoznanie tych samych okoliczność w innym postępowaniu ${ }^{28}$. Na tle konfliktów internetowych może to mieć kolosalne znaczenie, jeżeli uzna się (a za tym przemawia treść Regulaminu), że powód dochodzi odszkodowania lub zwrotu bezpodstawnie uzyskanych korzyści jedynie w odrębnym postępowaniu. Ustalenie sądu arbitrażowego o tym, czy zaszło naruszenie praw powoda i w jakim zakresie, będzie rzutowało na rozstrzygnięcie sądu powszechnego w sprawie roszczeń majątkowy$\mathrm{ch}^{29}$. Znaczenie wyroku arbitrażowego odzwierciedla również postanowienie Regulaminu, zakazujące umorzenia postępowania w wyniku cofnięcia pozwu przez powoda, jeżeli pozwany sprzeciwia się cofnięciu, a Arbiter uznaje, że ma on interes prawny w wydaniu orzeczenia rozstrzygającego sprawę co do istoty (art. 32 ust. 1 pkt i Regulaminu).

$\mathrm{Na}$ zakończenie warto zwrócić uwagę, że zgodnie ze swoimi Zasadami, NASK zobowiązuje się wykonać orzeczenie sądu rozstrzygające spór pomiędzy abonentem a osobą trzecią, dotyczący nazwy domeny (art. 18 Zasad). Jak zaznaczono powyżej, NASK ma możliwość podjęcia w stosunku do danej domeny technicznych działań wynikających z jego ogólnej kompetencji zarządzania domenami. Te czynności mogą polegać albo na usunięciu domeny, albo na jej „przeniesieniu” (zmianie delegacji) na rzecz innej osoby, albo na wprowadzeniu zmian w nazwie domeny. Wobec nieprecyzyjności redakcyjnej, można się zastanowić, czy chodzi o orzeczenie sądu powszechnego, czy sądu arbitrażowego, a jeśli tak, to czy przed stwierdzeniem jego wykonalności, czy po wydaniu tego postano-

${ }^{28} \mathrm{O}$ zarzucie res iudicata, por. szerzej T. ERECIŃski, J. Gudowski, Komentarz, I, cit., s. 668-670.

${ }^{29}$ Wytoczenie równoległych powództw powinno doprowadzić, zgodnie $\mathrm{z}$ art. 177 ust. 1 k.p.c., do zawieszenia postępowania przed sądem cywilnym, do czasu wydania rozstrzygnięcia przez sąd arbitrażowy. 
wienia przez sąd powszechny? Moim zdaniem, chodzi tu o orzeczenie pochodzące od każdego sądu, bez względu na jego rodzaj. W przypadku orzeczeń arbitrażowych NASK teoretycznie powinien je wykonać dopiero po uzyskaniu pełnej mocy prawnej, tj. po stwierdzeniu ich wykonalności. Jednakże, takie rozwiązanie formalnie prawidłowe, odsunęłoby w praktyce moment zaprzestania naruszeń, ponieważ domena, za pośrednictwem której dokonano naruszeń, byłaby praktycznie czynna do chwili zakończenia przez sąd powszechny swojego udziału w danym sporze.

Procedura UDRP, jako pierwowzór internetowych procedur arbitrażowych, uważana jest w literaturze za hybrydę pomiędzy procedurą mediacyjną a procedurą arbitrażową. Otóż z jednej strony, w drodze równoważenia sprzecznych interesów stron, doprowadza ona do osiągnięcia pożądanego kompromisu. Z drugiej strony, ponieważ nie jest to procedura obowiązkowa i definitywna, teoretycznie nie rozstrzygnie sporu ostatecznie ${ }^{30}$. Rzeczywistość jednak pokazuje, iż główne zalety UDRP (tj. postępowanie szybkie i tanie ${ }^{31}$ ) znakomicie sprawdzają się w praktyce. Głównym celem UDRP było i jest zwalczanie piratów internetowych, czyli podmiotów pozbawionych jakichkolwiek praw/interesów do spornej domeny. Rzadko kiedy takie podmioty podejmują się podważanie decyzji wydanych na podstawie UDRP, przez wdawanie się w dodatkowe, niepotrzebne spory sądowe. Jest więc pewnym paradoksem to, że postępowanie o ograniczonej skuteczności prawnej, okazuje się w praktyce skutecznym środkiem ochronnym. Z kolei nowo utworzony polski arbitraż wdraża stosunkowo tanią procedurę. Jednakże, biorąc pod

${ }^{30}$ Por. D. MAHER, The UDRP: The globalization of trademark rights, «IIC» 2002 nr 8, s. 937-938.

${ }^{31}$ Postępowanie kosztuje około 1000 USD dla jednej nazwy domeny, a rozstrzygnięcie następuje zwykle najpóźniej w ciągu 2 miesięcy od wytoczenia skargi. 
uwagę obligatoryjny udział sądu powszechnego ${ }^{32}$, nie przemawia to za szybkością w rozstrzygnięciu konfliktu. Pozostaje zatem otwarte pytanie, czy w dobie rosnącej liczby i wagi sporów internetowych, wzmocniona prawna skuteczność orzeczeń arbitrażowych w Polsce świadczyć będzie również o skuteczności arbitrażu jako środka rozwiązywania tego typu konfliktów?!

\section{The Chances of the Arbitration}

in the Solutions of Disputes Regarding Internet Domain Names

\section{Summary}

The paper deals with the Polish alternative dispute resolution (ADR) for internet domain names, which was introduced in January 2003 together with the establishment of a special Court of Arbitration. The Court acts within the Polish Chamber of Informatics, Technology and Telecommunication and it is based on a procedure drawn upon the well known UDRP (Uniform Domain Name Dispute Resolution Policy). The latter is actually applied by the main international organizations, e. g. such as Worldwide Intellectual Property Organisation.

The analysis focuses on the main procedural issues, such as type of conflicts that can be an object of the court examination, claims to be raised by the plaintiff, legal validity of the verdicts. Similarly to UDRP, the Polish proceedings provide only to the domain name's cancellation or its transfer for the benefit of the entitled person. The decision rendered by the Court acquires its full juridical force only after the ascertainment of its enforceability by an ordinary civil court. This means, that theoretically each proceedings concluded with a decision of the Court of Arbitration,

${ }^{32} \mathrm{~W}$ tym artykule pominięto rozważania związane $\mathrm{z}$ zasadami postępowania dowodowego przed sądem arbitrażowym. Zawiera ono pewne rozwiązania typowe dla procedury on-line, jednakże kładzie duży nacisk na kontradyktoryjność (możliwość przeprowadzenia rozprawy, dowody ze świadków, z przesłuchania stron, udział biegłego itp.) co przyczynia się do przedłużenia postępowania. 
should be followed by a compulsory formal examination in front of an ordinary court. Due to this, the Polish ADR seems to bring more juridical safety than the above-mentioned UDRP, yet the proceedings might be in practice protracted. In addition, such „enforced” decision would possess validity in law, in respect of the establishment of all facts, which could be further used as a ground to potential claims for damages or unjustified entichment. 